Volume: 01 Issue: 01 | April -2019

ISSN: 2663-8525 www.editoncpublishing.org

Langat, G. K., Editon Cons. J. Arts., Humanit. S. Stud., Double -Blind Peer Reviewed Journal

\title{
Examining the Perception of the Youths towards Kazi Kwa Vijana (Work for the Youth) Programmes in Kericho Municipality of Kericho County, Kenya
}

\author{
Gilbert Kiprotich Langat \\ Egerton University, Kenya \\ Corresponding Author Email: g_kiprotich@yahoo.com
}

\begin{abstract}
:
This study was intended to examine the perception of the youths towards this programme and find out how the programme has been effective in sustainable youth employment through the Kazi Kwa Vijana programme in Kericho Municipality. This study was carried out amongst youths and their coordinators who participated in the projects of the Kazi Kwa Vijana programme in this Municipality. The study employed Hertzberg's Two Factor theory which is effectively a theory of job satisfaction. Youths as employees of the KKV programme needed some hygiene and motivational factors referred herein as satisfiers and dissatisfiers. The challenges that affected the Kazi Kwa Vijana programme needed to be studied empirically so that remedial action is put in place for its sustainability in future and in the long run serve as a guideline for the many other projects to be initiated by the government. The study findings are useful to the Government of Kenya, Ministry of Youth Affairs and Sports, policy makers, NGOs, Kazi Kwa Vijana coordinators and all concerned stakeholders in devising workable strategies geared towards achieving the desired goals and objectives at the county and national level.
\end{abstract}

Key Terms: Perception of the Youths, Kazi Kwa Vijana Programme, Kericho Municipality.

$* * *$

How to cite this article in APA ( $6^{\text {th }}$ Edition)

Langat, G. K. (2019). Examining the perception of the youths towards kazi kwa vijana (work for the youth) programmes in Kericho municipality of Kericho county, Kenya. Editon Cons. J. Arts.,

Humanit. S. Stud., 1(1), 19-31.

*** 


\section{Editon Consortium Journal of Arts, Humanities and Social Studies (ECJAHSS)}

Volume: 01 Issue: 01 | April -2019

ISSN: $2663-8525$

www.editoncpublishing.org

Langat, G. K., Editon Cons. J. Arts., Humanit. S. Stud., Double -Blind Peer Reviewed Journal

\section{Introduction}

Youth unemployment is among the most significant development challenges in Third World countries today. In Kenya, over 15 million people live below the poverty line, while more than three million classified as unemployed. Youths account for about $55 \%$ of the unemployed in Kenya implying that unemployment is a predominantly youth issue [1]. Changes in economic policies have further aggravated the increasing levels of youth unemployment. Widespread youth unemployment remains a critical development challenge in Kenya. Additional negative factors that youth have to grapple with youth include lack of voice in the family, the community and the national arena, marginalisation; limited recreational facilities and poor representation in decision making. Specific areas that require attention include geographic transitions (including youth migration); transition from school to work; integrating the youth in urban areas; youth unemployment; youth groups at risk and implementation of youth policies and programmes [2].

The Government of Kenya launched the Kazi Kwa Vijana (Work for the Youth) programme in 2009, aiming to employ both urban and rural youths in labour-intensive public works projects like road maintenance, water harvesting, afforestation, and garbage collection. The most significant thing about the programme was their involvement in its management and implementation team consisting entirely of local youth.

The Kazi kwa Vijana programme in Kericho entailed planting of trees in public recreational gardens, schools, and water catchment; road repairs, bush clearing and trench digging for surface drainage. However, participation among the female youths was below expectations according to the coordinators. The mostly manual projects led to partial involvement as far as implementation was concerned. In addition to this, the negative attitude by the public domain on the programme and the little wages of Kshs. 250 per day that youth participating were paid among others affected the programme in surviving sustainability threshold.

Youth programmes in Africa are set up to tackle issues such as education, employment, and health among others. In some instances, a lot of money is allocated to these programmes only to end up being mismanaged leading to a bleak future for the targeted youths. The State of the Urban Youth 2010-2011 report notes that; policies, programmes, schemes and businesses solely aimed at youth are needed [3]. It further notes that issues such as gender and location as well as intergenerational factors; societal influence and income status affects upward social mobility and equal opportunity among the youths. As for the Kazi Kwa Vijana programme, participation among the female youths has been very low due to the nature of the manual projects. In addition to this, the negative attitude by the public to the programme and the peanut wages that youth participating were given as well as funds embezzlement among others has made it difficult for the programme to survive the threshold of sustainability.

Some deficits of Kazi kwa Vijana have been felt and witnessed across the country. The fact that stakeholders seemed not to have been sensitised and empowered on the objectives of KKV at the beginning, resulted in false perceptions and unreasonably high expectations among the youth. The first phase of KKV largely targeted unskilled labour, thus leaving out a substantial number of youth who have completed tertiary level education with possession of some vocational skills. The entire programme had a negative impression to the recipient youths due to delayed payments and lack of proper coordination in community projects undertaken by these participants.

The post-election violence of early 2008 in Kericho brought to focus the critical importance of addressing the problem of poverty and inequality and, in particular, the increasing 


\section{Editon Consortium Journal of Arts, Humanities and Social Studies (ECJAHSS)}

Volume: 01 Issue: 01 | April -2019

ISSN: $2663-8525$

www.editoncpublishing.org

Langat, G. K., Editon Cons. J. Arts., Humanit. S. Stud., Double -Blind Peer Reviewed Journal

problem of unemployed youths. The Country Social Analysis by the World Bank [4] has identified youth unemployment, particularly among males, as a significant contributor to tension and frustration in urban areas, and a matter of serious policy concern in the country. The Government of Kenya developed a plan in 2007 that emphasised the importance of adopting a coordinated and multi-sectoral approach to addressing the problem of youth unemployment, but less has been achieved mainly at the grassroots where several youths remain in disparity for income generating activities.

The various elected leaders pointed this outcry to the Government of Kenya about the need to overhaul the overall management and implementation of KKV programme. In addition,

community watchdogs had raised the same issue that phase one of this programme was the worst implemented where most youths reluctantly committed themselves to the then projects which were labour intensive and not conforming to their expectations given the being economic crisis at the time.

Kenya is faced with acute youth unemployment. The government attempted to address this problem by allocating resources to a range of projects under the Kazi kwa Vijana programme, but sustainable employment to the youths remained a challenge to various stakeholders of this programme. Since the time of carrying out this research, nothing had been unveiled as to what exactly led to the collapse of this programme. The study was therefore conducted to address these challenges.

\section{Methodology}

This study utilised a cross-sectional survey design. The descriptive analysis approach was chosen for the study because it intended to gain insight into a phenomenon as a way of providing basic information in an area of study [5]. The cross-sectional survey was adopted in this study based on the conceptual relationship between the independent variable and the dependent variable. Purposive sampling was employed to interview 9 coordinators to counter back and confirm the information given by the youths regarding the implementation of the KKV programme in Kericho Municipality. Primary data was collected through structured surveys, questionnaires from the youths on their views and perception on the various aspects of the KKV programme. Secondary data was obtained by examination and extraction of relevant information from the ministry of youth affairs, journals, magazines, conference papers, and scholarly books done by other researchers. Data was collected using face to face interview with 131 youth participants and 9 coordinators of KKV programme whom the researcher managed to reach at the time of research. Content analysis was conducted to identify the main themes that emerged from the responses given by the youths. The data obtained was analysed statistically using descriptive analysis techniques encompassing frequency distribution; percentages, mean, median, and standard deviation. For the analysis of the relationship between the independent variable and the dependent variable, correlation analysis and analysis of variance (ANOVA) were used to establish the association among the study variables.

\section{Literature Review}

Perception of youths towards Kazi Kwa Vijana programme It has been documented that Kenyan youth face many challenges [6]. The challenges identified include unemployment, restricted access to services and opportunities for quality education, health care, training, recreation, and peer pressure that sometimes push them to engage in criminal behaviour. Since independence, the country operated without comprehensive institutions, systematic and coherent policies targeting the rapidly emerging youth population. 


\section{Editon Consortium Journal of Arts, Humanities and Social Studies (ECJAHSS)}

Volume: 01 Issue: 01 | April -2019

ISSN: $2663-8525$

www.editoncpublishing.org

Langat, G. K., Editon Cons. J. Arts., Humanit. S. Stud., Double -Blind Peer Reviewed Journal

According to International Labour Organization (ILO), 85\%

of the world's youth live in developing economies, and the proportion is not likely to change much in the near future given the demographic trends in these economies [7]. They are 3.8 times more likely to be unemployed than adults, as compared to 2.3 times in industrialised economies. The Report also says that labour force participation rates for young people decreased in the world as a whole by almost four percentage points over the last decade, partly as a result of young people staying in education but also because many young people become so frustrated with the lack of employment opportunities that they simply drop out of the labour force [8].

The purposes of youth empowerment is a threefold [9], to build their capacity to realize their aspirations and boost their self-motivation and awareness, facilitate youth to forge partnerships with other groups in society, and instil a sense of ownership in the efforts to improve their wellbeing. Youths are the best resource for promoting development because they are agents of change, with the ability to provide sustainable solutions to their problems. According to the NYP [10] youths are empowered when they attain a position whereby they can take action based on their decisions, make free choices in life and accept responsibility for the action. The NYP [11] identifies several prerequisites for youth empowerment: a stable economic and social base; political will; adequate resources and a supportive legal and administrative framework; a stable environment for equality, peace, and democracy; access to knowledge and information and communication tools and skills; and a positive value system. Managers, leaders, teachers, and parents should identify new ways of educating youths about the future. Youth should no longer be taught what to learn, but how to learn, not what they are committed to but rather the value of commitment. Societal systems need to adopt open and flexible social norms. Adults should change from working for the youth to working with the youth [12].
To deal with the issues of youth empowerment and participation in national life, the NYP [13] proposes the following strategies: allowing youth to be involved at all levels of governance and in decision-making processes through affirmative action; Encouraging youths to engage in discussions on economic, political and social issues at all levels-local, national and global; Establish micro-finance programmes to cater for the financial needs of youth; Provide training in entrepreneurial, leadership and management skills for the youth and their organizations; and Encourage youth to fight against all form of injustice and discrimination.

There is scarcity of research documenting the reasons why youth in general (and more specifically, ethnic minority youth, both within and across ethnic and socioeconomic groups) choose to participate or not to participate in youth programs [14]. According to some studies, participation has been viewed as a dependent variable and therefore revealed peer, individual, and family factors associated with adolescents' participation in societal activities. Although these studies did not directly examine adolescents' decisions, they are nonetheless informative. Chavez and colleagues [15] found higher levels of acculturation to predict involvement in societal activities.

The other factors found to be associated with participation in community or school-based activities include parent endorsement and modelling of activity involvement [16] and having friends who endorsed the activity [17]. Gender has an impact on participation considering girls were found to prefer social [18], pro-social, and activities involving performance such as dances and bands as well as school involvement activities (i.e., student, government and pep club [19]. Men were more likely to report participation in sports [20]. Another gender-related finding concerns constraints on activity participation: Girls are more likely to 


\section{Editon Consortium Journal of Arts, Humanities and Social Studies (ECJAHSS)}

Volume: 01 Issue: 01 | April -2019

ISSN: $2663-8525$

www.editoncpublishing.org

Langat, G. K., Editon Cons. J. Arts., Humanit. S. Stud., Double -Blind Peer Reviewed Journal

report limitations such as self-consciousness, shyness, and the need for approval from friends [21].

French and Passmore [22] found, in their Australian sample, that the most important criteria for activities in leisure time were that they are "freely chosen and enjoyable." In an evaluation of Boys and Girls Club programs in large cities in the Southwest, young people, the majority of whom were African American or Latino and living below poverty levels, reported a "sense of safety and belonging, the acquisition of positive behaviours" (e.g., "getting along with others" and "staying out of trouble), and the development of competence and self-esteem most frequently as reasons for participating [23].

It is important to note that if the program is poorly designed, it will not be successful even though there are good policies and people. In contrast, if the development of the program is governed by well-articulated programs and the best available evidence, it will trigger the intended psychosocial mechanisms that will result in positive changes in the program participants. Furthermore, programs that are more likely to bring positive outcomes are those that are more interactive and developmentally appropriate, which can arouse the motivation of the program participants. In cross-cultural contexts, cultural sensitivity and use of proper indigenous cultural material are also important. Therefore the participation of the youth at the design stage is critical for the program success [24].

Research has demonstrated that youth involvement in program design is a strong predictor of participation [25]. In the 2006 Contra Costa Interfaith Supporting Community Organizations (CCISCO) survey, 79\% of Richmond youth indicated that they would attend recreation centres if their input was solicited in program development (Contra Costa Interfaith Supporting Community Organizations [26]. Basing on this finding, the survey recommended that organisations were to Work with youth leaders to engage their peers and ensure that all new programming is designed with the active input of youth.

However given the Kenyan context and the issues identified in this study, youth development should focus on Youth Participation; changing perspectives about the what the appropriate roles of young people in society are, and, in turn, providing them with real opportunities to participate and express themselves must be a fundamental principle of youth development, especially in Kenya and other African countries which generally tend to value the elderly at the expense of young people. Encouraging young people to participate in society and political life builds their self-esteem and allows them to make a positive contribution to their communities; it also helps change the negative images associated with young people [27].

Community-based programs are one channel for youth to gain skills and opportunities for changing the community in which they live [28]; [29]. Youth empowerment programs (YEPs) are interventions that regularly involve young people as partners and participants in the decision-making processes that determine program goals, planning, and implementation. Youth empowerment involves group interaction [30]. Consequently and exclusively, one-to-one youth development interventions, such as most mentoring schemes, would not meet inclusion criteria.

Kumpfer [31] investigated the types of programs which were most effective for youths in the United Kingdom. Results showed that programs with high peer interaction were more effective than programs with low peer interaction and that the delivery method instead of the program content determined the success of the program. In his discussion of principles of effective family-focused intervention, Kumfer identified several features of the program; comprehensive multi-component interventions, holistic coverage, high dosage, developmentally appropriate, early intervention, incorporation of cultural 


\section{Editon Consortium Journal of Arts, Humanities and Social Studies (ECJAHSS)}

Volume: 01 Issue: 01 | April -2019

ISSN: $2663-8525$

www.editoncpublishing.org

Langat, G. K., Editon Cons. J. Arts., Humanit. S. Stud., Double -Blind Peer Reviewed Journal

traditions into the program, which are intrinsic to program success.

Florin and Wandersman [32] pointed out that the following questions should be asked: Are capacities needed to put this intervention into place with quality? How will the intervention be carried out? How will the assessment of the quality of implementation be carried out? How well will the intervention work? How shall continuous quality improvement strategies be incorporated? In case the intervention is successful, how will it be sustained? Examining the factos that influence the quality of program implementation is important.

\section{Theoretical Framework}

The theoretical framework was derived from the Fredrick Herzberg [33] two-factor theories. This theory supports the study and presents that a motivated workforce will enhance the realisation of pre-planned program objectives. Hertzberg's two-factor theory is effectively a theory of job satisfaction. It is based on the information collected by Frederick Herzberg in 1959 in the USA. The data collected relates to the attitude of people towards work which is dependent on two factors; Hygiene/ maintenance which includes; policies and administration, supervision, working conditions, salary, job security among others and motivating factors; achievement, recognition for accomplishment, increased responsibility, opportunity for development and challenging work. According to him, hygiene factors make little contribution to provide satisfaction, and he called them dis-satisfiers as their absence causes dissatisfaction. They are not intrinsic to part of a job but are related to the conditions under which a job is performed.

Herzberg's motivation maintenance theory [34] argues that factors that cause job satisfaction have a stimulating effect on performance and morale, while those which cause job satisfaction have a negative impact. Positive factors are intrinsic to the job, while negative factors are extrinsic. That is people are happy with their work when they are doing a good job, which enhances their experience and expertise. On the other hand, job dissatisfaction is a result of shortcomings in the workplace, for example when workers are being paid low wages, working conditions are unsafe, or workers fear that they will lose of their jobs. Herzbergt et al. [35] identified two types of motivation, intrinsic and extrinsic motivation. Intrinsic motivators' are likely to have a deeper and long term effect because they are not imposed from outside but are inherent in individuals, while extrinsic motivators will have an immediate and powerful effect that may not necessarily last longer.

The two groups of factors affect job to job satisfaction; the model implies that it strongly influences approaches to job design and job enrichment. Youth who engaged in KKV programme may be intrinsically motivated since they earned income from the project, the intrinsic motivators' youth who engaged in KKV programme may have lacked (due to frustration which prevented them from working effectively). Concerning the KKV programme, several factors led to youth's satisfaction as employees of this programme to achieve its goals and objectives. The line managers of the programme did not enhance these factors in the first place on the recipient youths; thus this theory was useful in highlighting the expectations of the youths in the KKV programme. Thus Herzberg's motivation theory was pertinent to the impediments to the successful implementation of "KKV programme.

\section{Results and Discussion}

\section{Type of projects}

The study was keen on examining the kind of projects undertaken by the youths in the area of study from the time KKV programme was initiated to ascertain the level of their satisfaction in those projects. The youths, especially the educated ones, needed to take part in the projects that 


\section{Editon Consortium Journal of Arts, Humanities and Social Studies (ECJAHSS)}

Volume: 01 Issue: 01 | April -2019

ISSN: $2663-8525$ www.editoncpublishing.org

Langat, G. K., Editon Cons. J. Arts., Humanit. S. Stud., Double -Blind Peer Reviewed Journal

empower them while also helping them to access and learn from the life experiences and expertise of adults if the programme itself is youth initiated.

KKV programmes involved various projects, and this study was keen on determining youth participation in these projects. The respondents were asked to show the type of projects they participated in, and the result was given in Table 1

Table 1: Type of project

\begin{tabular}{|l|l|l|}
\hline Response & Frequency & Percentage \\
\hline Digging of trenches & 16 & 12.2 \\
\hline Planting of trees & 28 & 21.4 \\
\hline Bush Clearing & 37 & 28.2 \\
\hline Road Repair & 50 & 38.2 \\
\hline Total & 131 & 100 \\
\hline
\end{tabular}

Source; field data, 2013

The findings show that $38.2 \%$ of the respondents indicated that they had participated in road repair projects, $28.2 \%$ had participated in the bush clearing, $21.4 \%$ had participated in the planting of trees, and $12.2 \%$ had participated in digging of trenches. This implied that most projects that were represented in this study are manual and require no skills at all. The respondent youth especially the educated ones pointed out that the projects do not allow one's advancement of knowledge and empowerment in the current technological dynamic world. It is alarming to realise that a large percentage of them took part in road repair something which is known to be done with heavy machinery. It is clear that youths are confused about what they participated in, which is a pointer of lack of participation especially in planning for these projects, and with most youths indicating participation in bush clearing (28.2) and road repairs (38.2\%) tells about the dominance of a the same kind of jobs thus the programme lacks diversity in terms of professional.
This is in line with the ILO, 2012 report which indicated that in 2009 the Government of Kenya launched the Kazi kwa Vijana (Work for Youth) programme, to employ both urban and rural youth in labour-intensive public works like road maintenance, water harvesting, afforestation, and waste collection but the programme has not considered white collar programmes and engagements. However, the same report shows that the Government also supports young people financially for self-employment and entrepreneurial skills' development. This it appears did not feature in the gains experienced by participating youth in Kericho Municipality.

\section{Gender Participation in Projects}

This study considered the gender of the youth to influence participation in specific projects. It was assumed that female youth would tend to shy away from participating in labour-intensive projects as opposed to their male counterparts. The response in respect to youth participation in projects as per gender was as given in Table 2

Table 2: Youth participation in projects according to gender

\begin{tabular}{|l|l|l|l|}
\hline \multicolumn{2}{|c|}{} & \multicolumn{2}{|c|}{ Gender } \\
\cline { 2 - 4 } & \multicolumn{2}{|l|}{ Male } & Female \\
\hline $\begin{array}{l}\text { Type of } \\
\text { project }\end{array}$ & $\begin{array}{l}\text { Digging of } \\
\text { trenches }\end{array}$ & $17.4 \%$ & 0 \\
\cline { 2 - 4 } & $\begin{array}{l}\text { Planting of } \\
\text { trees }\end{array}$ & $17.4 \%$ & $30.8 \%$ \\
\cline { 2 - 4 } & $\begin{array}{l}\text { Bush } \\
\text { Clearing }\end{array}$ & $39.1 \%$ & $2.6 \%$ \\
\cline { 2 - 4 } & $\begin{array}{l}\text { Road } \\
\text { Repair }\end{array}$ & $26.1 \%$ & $66.7 \%$ \\
\hline Total & $100.0 \%$ & $100.0 \%$ \\
\hline
\end{tabular}

The findings from all the zones of the municipality show that $39.1 \%$ of the male youth and $2.6 \%$ of female youth participated in bush clearing, $26.1 \%$ of the male youth and 
Editon Consortium Publishing

Transforming Scholarly Publishing

\section{Editon Consortium Journal of Arts,} Humanities and Social Studies (ECJAHSS)

Volume: 01 Issue: 01 | April -2019

ISSN: 2663-8525 www.editoncpublishing.org

Langat, G. K., Editon Cons. J. Arts., Humanit. S. Stud., Double -Blind Peer Reviewed Journal

$66.7 \%$ of female youth participated in road repair projects, $17.4 \%$ of the male youth and $30.8 \%$ of female youth participated in planting of trees, while $17.4 \%$ participated in digging of trenches. This implied that as opposed to female youth, the male youth participated in all projects. Even though road repair was labour intensive, the highest proportion of female youth participated in this type of project as water vendors, rubbish collectors or flagging vehicles.

The respondent youths stressed the fact that in the current economic situation, where they consider themselves as a digital generation, such kind of projects be mechanised and structures put in place to implement them properly. The study found out that the participants hailed from the same locality meaning that the grass root coordinators emphasised locality even in their management and coordination of these projects. The fact the female youths did show remarkable participation in trench digging and bush clearing indicates the extent to which these projects were manual. Participating youths themselves availed the tools for carrying out these activities. This, the researcher can describe as "survival for the fittest" initiative. Youths pointed out that lack of tools of trade hampered many from participating in the subsequent projects. Besides, they raised the element of 'pay for measured work' technique as not comparable to the kind of tools used. This information is also presented in figure 1.

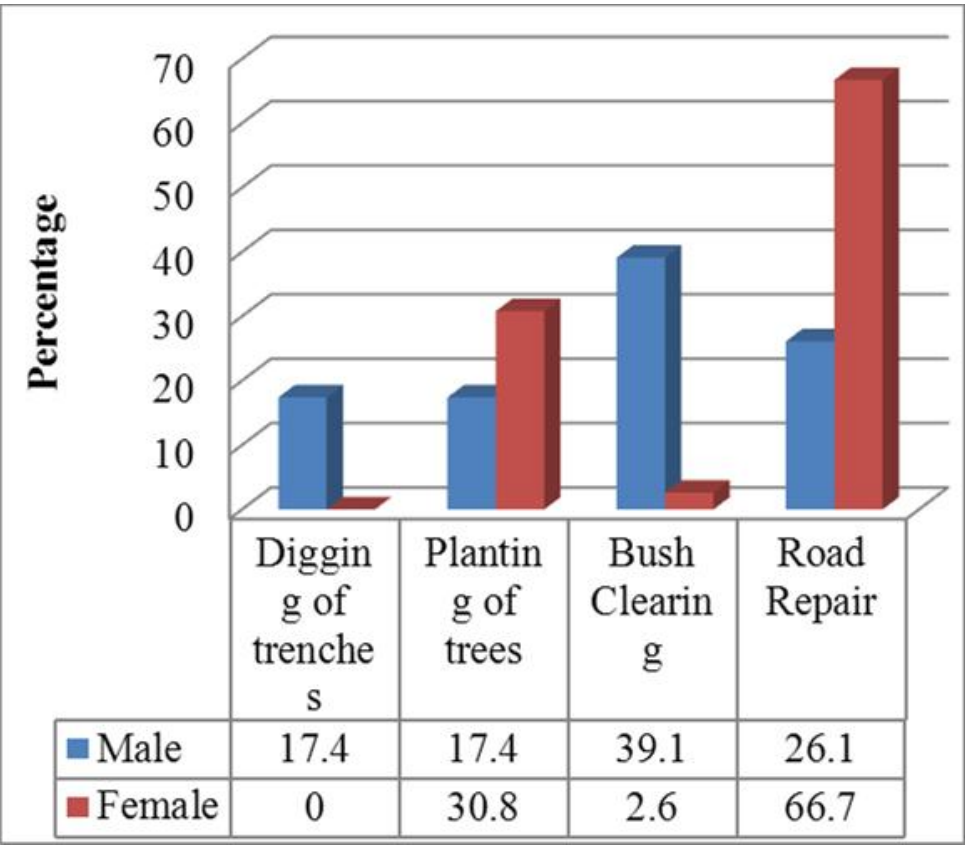

Figure 1: Youth participation in projects according to gender

It was noted that the intended plans heavily directed the KKV programme as per phase I of the national goals and objectives. In the area of study these projects were heavily manifest in the urban part of the Municipality namely; Kipchimchim, Central, Kimugung, and Kipchichim with a few projects undertaking at the rural part; Kipkoiyan, Kapkugerwet, Kapsuser, and Cheptororiet.

Understanding what impedes youths to choose to participate in KKV programme offered a full understanding of the decision making process as influenced by individuals, cultural and contextual factors. Overall, the reasons for participation were rated more highly than were the reasons influencing decisions not to participate. This suggested that the youths in this study placed more importance on the reasons contributing to their participation as compared to the reasons contributing to 


\section{Editon Consortium Journal of Arts, Humanities and Social Studies (ECJAHSS)}

Volume: 01 Issue: 01 | April -2019

ISSN: $2663-8525$

www.editoncpublishing.org

Langat, G. K., Editon Cons. J. Arts., Humanit. S. Stud., Double -Blind Peer Reviewed Journal

non-participation. The barriers to participation that youths perceived are important contextual factors. The key reasons for non-participation were personal obligations in the category of home duties, schooling or working elsewhere. This category offers a clearer understanding of the daily lives of these youth and suggests that addressing contextual issues, such as family responsibilities may be essential for increasing participation of youth in positive youth development programs such as KKV programme.

The youths who were interviewed in this study were more concerned about their personal and family responsibilities rather than national development issues. Some other clusters that were rated as important impediments to participation reflected external characteristics that may be critical socio-demographic factors that influence participation including; lack of stakeholders strategies, external constraints (lack of information and negative opinions of others), negative attitude towards coordinators of KKV programme and lack of safety during the implementation of projects. These findings, therefore, were consistent with critical elements of youth programs literature such as Eccles and Gootman [36]; Villarruel, Perkins, Borden and Keith [367, which stipulates that young people prefer environments that they feel safe and where they feel supported by the staff.

Perceptions as an impediment to the implementation process

This section presents the findings that sought to determine the perception to KKV programme as an impediment to successful implementation in Kericho Municipality. The respondents were asked to indicate their perceptions towards KKV programme. Six items were consequently used to elicit their opinions. Table 3 shows that except for the item, "low youth morale and interest would unavoidably lead to disinterest and subsequently implementation of the KKV projects $(M=3.17, S D=1.284)$ ", for which respondents seemed not to be sure.
They, however, pointed out those personal feelings, opinions, motivations, and prejudices influence implementation of KKV programme $(M=4.56, S D=0.623)$; that poor implementation of the KKV projects can be attributed to the lack of commitment and transparency by coordinators of the programme particularly through verbal reinforcement strategies $(M=4.34, S D=0.962)$; that behavior of youths that demonstrate level of disposition influence their perception and subsequently implementation of the KKV $(M=4.48, S D=0721)$; that level of education affected the perception of the youths and subsequently implementation of the KKV projects $(M=3.99$, 0.789 ); and that the quality of service rendered by unmotivated youths could affect the perception of the youths and subsequently implementation of the KKV $(M=3.86, S D=0.913)$.

The study also sought to establish the perception of the youths who were willing to be retained in the programme for projects to be implemented at an indefinite period with basis on their level of education during the time of research and also availability in terms of reliability of the programme.

Table 3: Those willing to remain in the system

\begin{tabular}{|l|l|l|}
\hline Level of education & Frequency & Percentage \\
\hline Primary & 95 & 72.5 \\
\hline Secondary & 5 & 3.8 \\
\hline College/university & 31 & 23.7 \\
Total & 131 & 100.0 \\
\hline
\end{tabular}

The findings show that a large number of youths (72.5\%) with primary level as the highest level of education were willing to be retained while their secondary level (3.8\%) said they could remain in the system. It was interesting to note 


\section{Editon Consortium Journal of Arts, Humanities and Social Studies (ECJAHSS)}

Volume: 01 Issue: 01 | April -2019

ISSN: $2663-8525$

www.editoncpublishing.org

Langat, G. K., Editon Cons. J. Arts., Humanit. S. Stud., Double -Blind Peer Reviewed Journal

that a good number in possession of university education $31(23.7 \%)$ participated in this programme.

The study sought to determine their perception level to the programme that even though there were challenges here and there, the positive perception of the programme by these youths could still be a saviour to KKV in the future. Those in primary by the time felt that they still had time to participate in the programme. It is clear that given their ages and exposure, these groups of youths have not developed the concept of self-development and empowerment, something which can be attributed to the level at which external influences especially the peers and the parents impart on them. This can, therefore, illustrate that perception to KKV depends on age, ability to succumb to external pressure to withdraw or the need to invest in own development.

Those in the secondary level, however, felt that it was time to further their education; thus there was no more time to engage in KKV especially with its consistent underperformance. These groups of youths could no longer be retained. The findings showed that 86 these categories of youths were the largest in the number of participants across the four ranges of projects under the KKV programme. It implies therefore that if they are among the largest category of participants, their mass withdrawal from the programme led to a negative and subsequently a negative attitude to the KKV programme.

It can also be deduced that educated youths in possession of higher academic qualifications have to some degree a positive attitude in the programme. However, their participation was low 24 (18\%), given the nature of projects. However, those who participated were optimistic that the status quo could shift to a positive scale as they were faced with employment challenges upon completion of their studies. The prevailing collapse of KKV finally resulted in their negative attitude as to whether the programme could alleviate their joblessness. As things stand now, the programme was not revived, and thus their perception was that the programme is "permanently dead."

The study was also keen on determining the extent to which influence from civic leaders had on the participants. As noted earlier, the researcher was puzzled to carry out this research due to its heightened politics over it by the leaders of that time as to the sustainability of the programme. Respondents were asked to state if at all they were influenced to perceive the programme in a manner that could derail its operations. The civic leaders in question include; aspiring politicians or elected ones during the anticipated 2012 General Elections, the clergy and village elders among others. The results from these responses were then tabulated as follows;

Table 4:

\begin{tabular}{|l|l|l|}
\hline & Frequency & Percentage \\
\hline Non- educated & 122 & $93.1 \%$ \\
\hline Semi-educated & 9 & $6.9 \%$ \\
\hline Total & 131 & $100.0 \%$ \\
\hline
\end{tabular}

It can be asserted that external influences arise with the level of education of individual youth participant. Those with primary level and below 122 (93.1\%) were highly victims of these dragging. The programme then became a point of attack between politicians of that time, both at the local and national level. Those who felt that they had massive support of these desperate youths emphasised the fact that the government had failed Kenyan youths by mismanaging the KKV programme. The respondent was categorical that KKV was a campaign tool before 2013 to 2013 general elections. The study found that factors to have significantly contributed to the negative perception by the youths in Kericho Municipality resulted in withdrawal and finally the collapse of the programme. 


\section{Editon Consortium Journal of Arts, Humanities and Social Studies (ECJAHSS)}

Volume: 01 Issue: 01 | April -2019

ISSN: $2663-8525$ www.editoncpublishing.org

Langat, G. K., Editon Cons. J. Arts., Humanit. S. Stud., Double -Blind Peer Reviewed Journal

Those in possession of higher education $9(6.9 \%)$ pointed out that education enables one to make their decisions based on what is ethically and morally acceptable in society. This may explain the fact that a few of them were dragged by politicians to perceive the KKV programme in either way. Most of the respondents, however, noted that their parents played critical roles in their choice to participate which subsequently contributed to their perception with time.

Those interviewed pointed that their parents endorsed their involvement and later on were advised that the programme was no longer reliable and that it was unworthy given the national outcry about the failure of KKV programme. Sociologically, this can be perceived as a dictatorship, and so the programme was negatively reputed across the public domain with a view that no payment was effected for projects implemented. It is clear from these findings that the youths may have engaged in other economic activities owing to this negative perception and influences thus posing implementation challenges to the stakeholders

In summary, the youths participating in the Kazi Kwa Vijana programme perceived this programme as a scheme put in place to help them address poverty and unemployment of which they willingly participated in it. The local community supported the program, and this favoured its implementation. The youth had a positive attitude because most of them were semi-educated.

\section{Conclusions}

The wages paid to the youth for services offered to the programme were little, but this did not discourage participation and programme implementation since the youth were able to get other non-financial gains such as security, societal recognition, and self-esteem and enhanced social welfare. The Government of Kenya to consider reviewing its policy in respect to the rates of wages paid to the youth participating in its programmes as well as the operationalisation to achieve its intended objectives.

\section{References}

[1] United Nations Human Settlement Programme, (2010). Youth Entrepreneurship and Empowerment. UN-Habitat: Nairobi.

[2] UNDP (2011).

[3] UN Habitat (2010). See note 1.

[4] World Bank (2007). Development and the Next Generation. Washington DC: World Bank.

[5] Bless \& Higson-Smith (2000).

[6] World Bank (2007). See note 4.

[7] ILO (2004): Global Employment Trends for Youth. International Labor Organization, Geneva. Retrieved from http://www.ilo.org/public/english/employment/strat/download/getyen.pdf

[8] ILO (2004). See note 7.

[9] GoK, (2006), Kenya National Youth Policy. Nairobi: Government Printer. 


\section{Editon Consortium Journal of Arts, Humanities and Social Studies (ECJAHSS)}

Volume: 01 Issue: 01 | April -2019

ISSN: 2663-8525

www.editoncpublishing.org

Langat, G. K., Editon Cons. J. Arts., Humanit. S. Stud., Double -Blind Peer Reviewed Journal

[10] NYP (2006).

[11] NYP (2006). See note 10.

[12] GoK (2006). See note 9.

[13] NYP (2006). See note 10.

[14] Weiss, H. R. (2005). More Than Just Being There: Balancing the Participation Equation. New Direction for Youth Development, 105, 15-31.

[15] Chavez, E. L., Davalos, D. B. \& Guardiola, R. J. (1999). The Effects of Extracurricular Activity, Ethnic Identification, and Perception of School on Student Dropout Rates. Hispanic Journal of Behavioral Sciences, 21, 66-77.

[16] Fletcher, A. C., \& Mekos, D. (2000).Parental Influences on Adolescent Involvement in Community Activities. Journal of Research on Adolescence, 10, 29-48.

[17] Huebner, A. J., \& Mancini, J. A. (2003). Shaping structured out-of-School Time use among Youth: The Effects of Self, Family, and Friend Systems. Journal of Youth and Adolescence, 32, 453-463.

[18] French, D. \& Passmore, A. (2001). Development and Administration of a Measure to Assess Adolescents' Participation in Leisure Activities. Adolescence, 36, 67-75.

[19] Barber, B. L. \& Eccles, J. S. (2001). Young Adult Pathways Linked to Adolescent Activity Involvement and Social Identity. Journal of Adolescent Research, 16, 429-455.

[20] Chavez, E. L., Davalos, D. B. \& Guardiola, R.J. (1999). See note 15.

[21] Crawford, D., Godbey, G. \& Raymore, L. (1994). Self-esteem, Gender, and Socio-economic status: Their Relation to Perceptions of Constraints on Leisure among Adolescents. Journal of Leisure Research, 26, 99-118.

[22] French, D. \& Passmore, A. (2001). See note 18.

[23] Busser, J. A. \& Carruthers, C. P. (2000). A Qualitative Outcome Study of Boys and Girls Club Program Leaders, Club Members, and Parents. Journal of Park and Recreation Administration, 18, 50-67.

[24] Florin, P. \& Wandersman, A. (2003): Community Interventions and Effective Prevention. American Psychologist, 58, 441-448.

[25] Borden, L. M., Carlton, A., Keith, J. G., Stone, M., \& Perkins, F. A. (2006). Challenges and Opportunities to Latino Youth Development: Increasing Meaningful Participation in Youth Development Programs. Hispanic Journal of Behavioral Sciences, 28, 187-208.

[26] Contra Costa Interfaith Supporting Community Organizations (CCISCO), (2007): Unlocking the Power of the Iron Triangle - Killing time: The Problem of Youth Violence in Richmond and the Need for Youth Recreation Program. Retrieved from http://www.ccisco.org/research.php.

[27] Contra Costa Interfaith Supporting Community Organizations (CCISCO), (2007). See note 26.

[28] Barton, W. H., Jarjoura, R. \& Watkins, M. (1997): Youth and Communities: Towards Comprehensive Strategies for Youth Development. Social Work, 42, 483-494.

[29] Larner, M. B. \& Zippiroli, L. (1999): When School is Out: Analysis and ' Recommendations. The Future of Children, 9(2), 4-10. 


\section{Editon Consortium Journal of Arts, Humanities and Social Studies (ECJAHSS)}

Volume: 01 Issue: 01 | April -2019

ISSN: $2663-8525$

www.editoncpublishing.org

Langat, G. K., Editon Cons. J. Arts., Humanit. S. Stud., Double -Blind Peer Reviewed Journal

[30] Cargo, M., Grams, G., Green, L., Ottoson, J. \& Ward, P. (2003): Empowerment as Fostering Positive Youth Development and Citizenship. American Journal of Health Behavior, 27, 66-79.

[31] Kumpfer, K. L. (2003): Family-Strengthening Approaches for the Prevention of Youth Problem Behaviors. American Psychologist 58, 457-465.

[32] Florin, P. \& Wandersman, A. (2003). See note 24.

[33] Fredrick Herzberg (1959).

[34] Herzberg et al. (1957).

[35] Herzberg et al. (1957), see note 34.

[36] Eccles \& Gootman, (2002).

[37] Borden, F., Carlton, M., Keith, J. G, Perkins, D. L., Villaruel, A. (2007): Participation in Structured Youth Programs: Why Ethnic Minority Urban Youth Choose to Participate or not to Participate. Youth and Society, 38, $50-65$. 